\title{
Hypnoteaching In Islamic Law Learning
}

\author{
Nurul Istiani \\ Pascasarjana IAIN Pekalongan \\ Athoillah Islamy \\ IAIN Pekalongan
}

\begin{abstract}
This study aims to find the implementation of hypnoteaching method in fiqh (Islamic law) learning in Madrasah Tsanawiyah NU Sunan Kalijaga, Adiwerna Tegal, Central Java. This research is a qualitative research, which is a case study. Data sources of this research are interviews and varius literature on hypnoteaching. There are two big conclusions in this research. First, the hypnoteaching method is a learning method that involves cognitive, affective and psychomotor aspects of students through positive suggestions. Second, the application of hypnoteaching fiqh learning in the field works effectively related to the synergy between the principles of hypnoteaching and the existing implementation plan of learning. However, there are still inhibiting factors, namely the minimum number of teachers who have competence in the application of hypnoteaching.
\end{abstract}

Keywords: method, hypnoteaching, learning, fiqh. 


\section{Intriduction}

The dynamics of education are always dynamic in producing various updates, developments and even changes in the various aspects that cover it. ${ }^{1}$ As in the context of renewal and development of learning method in Islamic studies. ${ }^{2}$ However, the practice is uncertain as expected, as is the case in fiqh learning which so far tends to be taught through conventional methods. The learning process of figh which is usually practiced is by delivering the material and then proceed with memorization and practice. Such conditions tend to be monotonous and often cause boredom for students. Not infrequently, for reasons of pursuing curriculum targets, educators burden students with so much material without regard to whether students really understand, are interested in what is taught or not. Though a monotonous learning atmosphere will create an uncomfortable atmosphere and can even cause stress. This non-conducive condition will make it very difficult to increase the interest in fiqh learning and can achieve optimal learning outcomes. ${ }^{3}$ From this it follows that the importance of new creativity in the use of fiqh learning method.

The existence of hypnoteaching method is a manifestation of creative as well as innovative art in terms of renewing the learning method. Such statement is caused by the hypnoteaching method which is a learning method that combines teaching and learning with the art of hypnosis. ${ }^{4}$

${ }^{1}$ Nurul Istiani, Athoillah Islamy, "Objektifikasi Nilai-nilai Psiko-Sufistik dalam Pendidikan Spiritual," Hikmatuna : Journal for Integrative Islamic Studies, Vol.4, No.2 (2018), 234.

2 Ema Amalia, Ibrahim, "Efektivitas Pembelajaran Fiqih dengan Mengunakan Metode Demonstrasi di Madrasah Ibtidaiyah Negeri Desa Penggage-Muba," JIP: Jurnal Ilmiah PGMI, Vol. 3, No.1, (2017), 99.

3 Syukrawati, "Pengembangan Metode Pembelajaran Fiqih Untuk Siswa Madrasasah Ibtidaiyah (MI),"1.

4 Nurul Istiani, Athoillah Islamy, "Application Of Hypnoteaching Method In Spiritual Values Learning," Irfani, Vol.14, No.1 (2019), 36. 
Therefore, it is interesting to make it a new method in fiqh. In this study, the author will explain the practice of hypnoteaching in fiqh learning in Madrasah Tsanawiyah (MTs) NU Sunan Kalijaga, Adiwerna Tega, Central Java.

\section{Discourse on Hypnoteaching As a New Art in the Learning Process}

Hypnoteaching is a new term in the context of developing learning methods. In terms of language, hypnoteaching is a combination of two words consisting of the word hypnosis ${ }^{5}$ dan teaching. Hypnosis means suggesting and teaching means teaching. ${ }^{6}$ Thus it can be concluded that hypnoteaching is an attempt to suggest students in the context of learning.

While in terms, there are variants of the definition. According to Ibn Hajar, hypnoteaching is the art of communication by suggesting students to become smarter. In this case, Ibnu Hajar added that hypnoteaching is a combination of five learning methods, namely: quantum leraning, accelerated learning, power teaching, Neuro Lingustic Programing (NLP), and hypnosis. Ibn Hajar explained that hypnoteaching emphasizes subconscious communication, both in the classroom and outside the classroom. This can be done with suggestion and imagination. ${ }^{7}$ In this case, Novian Triwidia Jaya, also explained

${ }^{5}$ Hipnosis merupakan tehnik untuk memperkecil critical area, sehingga informasi yang di dapat lebih mudah memasuki sub conscious, sehingga dapat menemukan hypnosis state, yakni kondisi kesadaran manusia lebih mudah menerima saran. Nurul Istiani, Esti Zaduqisti, "Konsep Strategi Theistic Spritual dalam Layanan Bimbingan Konseling dan Psikoterapi Islam." Religia, Vol. 20, No.2 (2017), 195 .

${ }^{6}$ N. Yustisia, Hypnoteaching Seni Ajar Mengeksplorasi Otak Peserta Didik ( Jogjakarta: Ar-Ruz Media, 2012), 75.

${ }^{7}$ The ability of suggestion that is constantly remembered in the brain and is able to deliver someone to what is thought. While imagination is the process of imagining something that is applied first. In this case a teacher must be able to let students express and imagine. 
that hypnoteaching is a combination of teaching that involves the conscious and subconscious mind. Novian added that hypnoteaching is a creative, unique and imaginative learning method. Before the implementation of learning, students are conditioned to learn. Thus students can participate in learning in fresh conditions and are ready to receive learning material. To prepare for this, a teacher is also required to be stable, both psychologically and psychologically. That way the teacher can also have full readiness in teaching their students. ${ }^{8}$

Furthermore, Suwanto explained that hypnoteaching is a method of teaching using subconscious languages that gives rise to student suggestions for students to concentrate fully on the knowledge delivered by the teacher. ${ }^{9}$

From the various explanations above, it can be understood that hypnoteaching is a learning method that combines teaching and learning activities with the science of hypnosis. With this method it is expected to create a more pleasant, peaceful, calm, relaxed and enjoy learning atmosphere. In addition, it can also be understood that the method of hypnoteaching only plays at the level of the "learning process" instead of the problem of educational philosophy and policy.

So that the learning process can run effectively, the application of hypnoteaching method can be done in several stages ${ }^{10}$, such:

Ibnu Hajar, Hypnoteaching Memaksimalkan Hasil Proses Belajar Mengajar dengan Hpnoterapi ( Jogjakarta : Diva Press, 2011), 75.

8 Novian Triwidia Jaya, Hypnoteaching Bukan Sekedar Mengajar (Bekasi : D-Brain, 2011), 41.

9 Suwanto, "Perbedaan Kemampuan Pemecahan Masalah Matematika Siswa Yang Diajar Menggunakan Hypnoteaching Dan Pendekatan Ctl Pada Pokok Bahasan Pecahan Di Kelas VII SMP Negeri 27 Medan Tahun Ajaran 2011/2012" (Medan: Fakultas Matematika: Jurnal Penelitian Universitas Negeri Medan, Juli, XXII, 2012), 6 .

${ }^{10} \mathrm{Ibnu}$ Hajar, Hypnoteaching Memaksimalkan Hasil Proses Belajar Mengajar dengan Hpnoterapi ( Jogjakarta : Diva Press, 2011), 101-103. 
First, intention and motivation. Intention and motivation are the main keys so that it can bring concentration in the field being studied. The existence of motivation in this case can be a driving force for students to be able to act in realizing a predetermined learning orientation. ${ }^{11}$ Second, pacing. Pacing is the equalization of brain waves, body movements, and language to students so that educators are able to penetrate the world of student learning. ${ }^{12}$ Third, leading. This process is carried out by educators to be able to lead and direct students to create a comfortable mood so that it can make learning more effective and efficient. Fourth, the use of positive sentences. This is done so that educators are able to enter the subconscious so that they can fortify negative suggestions. Fifth, praise. Giving praise can be done in shaping one's self-concept so that it can trigger to do something. Sixth, modeling. This process can be done by giving good figures to students through consistent examples and behaviors.

From this understanding, it can be understood that in the learning process by using the application of hypnoteaching methods must use steps that are applicable, correlative and synergistic.

In addition to using synergistic steps, the application of hypnoteaching methods in learning has several advantages. First, the learning process seems more exciting. Second, being able to establish harmonious relationships between teachers and students. Third, Attracting students' attention so that it can bring

11 Athoillah Islamy, " Dialectic Motivation, Behavior And Spritual Peak Experience In The Perspective of Islamic Psychology," alfuad journal, Vo.3, No.2 (2019), 36.

12 The purpose of education is to foster a rounded pattern of human personality through psychiatric exercises, brain intelligence, reasoning, feelings and senses. This education must serve human growth in all aspects, both spiritual, intellectual, imagination, physical, scientific, and language. Saihu, "Konsep Manusia dan Implementasinya dalam Perumusan Tujuan Pendidikan Islam Menurut Muratdah Mutahhari," Andragogi : Jurnal Pendidikan Islam, Vol.1, No.1 (2019), 211. 
up creativity, Fourth, Overcoming the boredom of learning. Fifth, overcome the problem of student learning by using the power of mind. Sixth, treat smoking addiction. Seventh, overcoming students' mindset problems. Eighth, arouse student enthusiasm for learning. Ninth, treating spycosomatic diseases. Tenth, break students' egos. ${ }^{13}$

As for the effort to synergize the learning implementation plan with the implementation of hypnoteaching, it can be done through the following phases:

\section{Planning phase}

follows

In this planning phase it is divided into two steps as

a. Pre learning

Before the implementation of learning, one or two days a teacher prepares material to be delivered.

b. Apperception.

Before starting the lesson, the teacher gives greetings, prayers, absences. After these three things, the teacher invites students for relaxation, which is then accompanied by explanations of the material.

\section{Learning phase}

a. Exploration

In this exploration activity the teacher can instruct students to explain what is meant by the material.

b. Elaboration

In this elaboration activity the teacher can demonstrate the material. Meanwhile, students pay attention and practice what they see.

c. Confirmation

In this case the teacher can ask questions about things that are not understood by students. But students are also required to be active in the feedback process.

\section{Evaluation Phase}

At this evaluation stage it can be done during the learning process and the presentation of assignments (material). This is because in the process there are values of responsibility,

13 http://www.slideshare.net/novrizalbinmuslim/buku-ajarhypnoteaching-2013-revisi.Diakses, 21/06/2017. 
discipline, mutual assistance, mutual respect and responsibility. In addition, this evaluation can also be done on learning outcomes by asking about what material has been delivered. In this evaluation process, a teacher can also give rewards (punishment) and punishment (punishment) to students. With the reward or punishment it is expected to encourage students to appreciate the spiritual values that exist in the material.

Based on the explanation of the example hypnoteaching application above, it can be understood that the application of hypnoteaching method is a technical method whose implementation is very conceptual and systematic. In the application of the hypnoteaching method also shows a form of synthesis between the concept of teaching and learning activities with the science of hypnosis in instilling and growing students' intelligence through positive suggestions.

\section{Analysis of the Application of Hypnoteaching in Fiqh Learning at MTs NU Sunan Kalijaga Adiwerna Tegal \\ Planning Aspect}

Planning the implementation of hypnoteaching method in fiqh learning at MTs NU Sunan Kalijaga has been well structured. This is evidenced by the creation of RPP (Learning Implementation Plan). In the RPP (Learning Implementation Plan), the process of fiqh learning regarding qurban material was included with the hypnoteaching method. In apersesi applied in greetings, prayers, absences, invite students to relax and explain learning subject matter. In exploratory activities, the teacher asks students to mention the meaning of slaughter, the teacher also facilitates students to discuss with their friends. Then in the elaboration activity, students observe the teacher's demonstration about the slaughter, the student reads the book and explains the terms and rules of the slaughter by means of discussion facilitated by the teacher. As for the confirmation activity, a teacher gives affirmation when students conduct discussions, presentations, and provisions and the sunnah of slaughter. Then proceed with the final activity, namely by means of the teacher with students concluding the results of the discussion, the teacher provides motivation to study hard, 
provides questions to be done as an evaluation of students' abilities and understanding and continues with a closing. ${ }^{14}$

The steps of the Hypnoteaching method applied in PreLearning are in motivating yourself and mastering the material. Motivating yourself is useful for motivating a teacher and mastering useful material in order to convey the material well. This self-motivation starts from great intention and strong determination so that it will foster commitment in the occupied field. A teacher must also comprehend subject matter comprehensively. This can also be done by actively involving students in the learning process. In addition, teachers can also strive to conduct informal interactions with students, so that teachers can give students learning responsibilities.

The steps of the Hypnoteaching method applied in apperception are pacing which is useful for equalizing thoughts before the teacher conveys material, Gives Positive Words is useful for providing positive perceptions of the material to be conveyed and can motivate students, mastering useful material in order to convey material properly . In doing pacing, teachers usually use slang which is rife and commonly used by students. Teachers also often associate the theme of the lesson being discussed with the theme that is currently rife discussed by students, so that students will feel comfortable to interact with the teacher. Giving positive words to students also greatly affects the condition of students in receiving subject matter. The use of positive words that are commonly used by teachers when students are busy and noisy in the classroom that is the teacher does not use the word "do not be crowded" but the teacher uses the word "please calm down". In this apperception activity a teacher must also master the learning material, because in the learning process the teacher is able to provide opportunities for students to be able to provide feedback.

The difference in curriculum applied in fiqh learning is in the RPP (Learning Implementation Plan). Although not much different from the curriculum in the general lesson plan, in this lesson plan the learning of fiqh uses hypnoteaching methods, so

${ }^{14}$ Dokumentasi Rencana Pelaksanaan Pembelajaran MTs NU Sunan Kalijaga. 
that the apperception and evaluation section has a slight difference.

. This can be seen in the following table that illustrates the differences between RRP who use hypnoteaching methods or those who do not use them.

\begin{tabular}{|c|c|}
\hline $\begin{array}{l}\text { RPP Without Hypnoteaching } \\
\text { Method }\end{array}$ & $\begin{array}{l}\text { RPP Using the Hypnoteaching } \\
\text { Method }\end{array}$ \\
\hline $\begin{array}{l}\text { Initial activity: } \\
\text { Apperception: } \\
\text { Give questions about past lessons } \\
\text { and material for slaughter, qurban } \\
\text { and aqiqah. } \\
\text { Motivation: } \\
\text { Provides information about the aims } \\
\text { and benefits of learning about } \\
\text { slaughter, sacrifice and aqiqah and } \\
\text { the procedures that can be applied in } \\
\text { daily life. } \\
\text { - } \\
\text { Exploration } \\
\text { - The teacher asks students to } \\
\text { mention the meaning of slaughter. } \\
\text { Elaboration } \\
\text { - Students observe teacher } \\
\text { demonstrations } \\
\text { - Students explain the terms and } \\
\text { practices of slaughter. } \\
\text { Confirmation } \\
\text { - The teacher gives affirmation of } \\
\text { the material to students. } \\
\text { End activities } \\
\text { - The teacher concludes the material } \\
\text { - The teacher gives motivation } \\
\text { Closing }\end{array}$ & $\begin{array}{l}\text { Initial activity: } \\
\text { Apperception: } \\
\text { - Greetings, prayers, absences, } \\
\text { checking student readiness. } \\
\text { - Invite students to relax to prepare } \\
\text { themselves students before } \\
\text { learning. } \\
\text { - Explain the material to be studied } \\
\text { together. } \\
\text { - Explain the purpose of learning } \\
\text { subject matter. }\end{array}$ \\
\hline
\end{tabular}


Although the curriculum used in these fiqh subjects is the same, but in the planning section there are differences, namely the apperception section. Looking at the differences in the above table, it is illustrated that the fiqh learning curriculum that applies the hypnoteaching method in fiqh learning lies in the curriculum of the planning section. This can be known through the RPP (Learning Implementation Plan).

In the lesson plan that does not apply the method of hypnoteaching, apperception is done by giving questions about past lessons that serve to recall the lessons that have been given. Then proceed with material about the slaughter, qurban and aqiqah.

Whereas in the lesson plan that applies the method of hypnoteaching in fiqh learning, apperception is done by the teacher entering the classroom by saying greetings followed by students' attendance. The way of attendance used by the teacher is by calling students in accordance with the name contained in the timesheet. Then students whose names have been called say the word present for men and hadiroh for women.

The next thing that is done by a teacher is checking the readiness of students by relaxing students in order to make students able to relax so that it will be easy to catch what the teacher teaches. This relaxation process begins with Pacing which equates brain waves, breathing, and perceptions between teacher and student, followed by connectivity or directed by leading, ie students are able to follow what the teacher wants with their students. Teachers also often relax students by practicing smiling. The trick is that students who had been sitting were told to stand up and face their classmates, then on the count of three they laughed at their friends.

Based on the table above it can be concluded that although there are differences, the essence remains the same. And with the application of this hypnoteaching method able to have a positive impact, the application of this method has the support of both the students, teachers, or the principal so that the application of the method needs to be maintained.

Implementation Aspect 
Implementation is the implementation or application. ${ }^{15}$ While the hypnoteaching method is the fastest and most effective method for getting into the subconscious mind. ${ }^{16}$ Thus what is meant by the implementation of the hypnoteaching method is the implementation or application in the context of suggesting students from the conscious to the subconscious so that what is conveyed will be easily captured and understood. The things contained in the implementation are exploration, elaboration and confirmation.

The steps of the Hypnoteaching method applied in exploration are pacing that is useful for exploring students about the material being studied, Leading is useful for exploring students about the material being studied, Providing Positive Words and modeling is useful for facilitating students when discussing, mastering useful material in order to convey the material properly. Pacing and leading used in exploration activities this time are the same as the application in the apperception section. Giving positive words used by teachers in the exploration process this time is also usually "you are great like a suction machine" with the word that is able to arouse students' enthusiasm in receiving the learning process.

The steps of the Hypnoteaching method applied in elaboration are Leading which is useful for directing and motivating students, giving Positive words useful for directing and motivating students, modeling is useful for when teachers demonstrate about learning material, mastering useful material in order to convey material with good. Leading, positive words and mastery of the material used in the elaboration process this time are the same as leading application in the process of apperception or exploration.

\footnotetext{
${ }^{15}$ Departemen Pendidikan Nasional, Kamus Besar Bahasa Indonesia Pusat Bahasa, Edisi Ke empat ( Jakarta: PT. Gramedia Pustaka Utama, 2008), h. 529.

${ }^{16}$ Freddy Faldi Syukur, Menjadi Guru Dahsyat Guru yang Memikat Melalui Pendekatan Tehnologi Pikiran Bawah Sadar Hypnoteaching dan NLP ( Bandung: Remaja Rosdakarya, 2010), h. 97.
} 
The steps of the Hypnoteaching method that are applied in the confirmation are giving Positive words useful to direct and motivate students, give useful praise to motivated students, master the material used in order to convey the material well. Motivation used in this confirmation activity is useful to strengthen the material that has been submitted so that it can be concluded together.

Based on the implementation analysis above, it can be concluded that the implementation of hypnoteaching method in fiqh learning is in accordance with the plan made in the RPP (Learning Implementation Plan) and is in accordance with the steps that have been carried out in the hypnoteaching method, which must have an intention in oneself, pacing, leading, using positive words, giving praise, modeling, and the teacher must master the learning material.

The implementation of hypnoteaching method in fiqh learning in MTs NU Sunan Kalijaga is good, this can be seen from the process of implementing hypnoteaching method in fiqh learning that has been able to change the understanding of students. This is supported by an interview with Faqihatun Lestari who said that the relaxation process carried out can make students more able to concentrate, so that the material taught will be easy to enter. ${ }^{17}$

In line with the interview of Muhammad Hambali who said that this hypnoteaching method can train the concentration or focus of students. So that when students have focused, the material delivered and taught by teachers will be easily understood by students. ${ }^{18}$

So it can be concluded that the implementation of hypnoteaching method in fiqh learning has been carried out well because it sees from the learning process that has been able to provide understanding of students and train concentration.

This hypnoteaching method is able to equate brain waves, perception and the connection between teacher and

\footnotetext{
${ }^{17}$ Faqihatun Lestari, Siswa MTs NU Sunan Kalijaga, Wawancara Pribadi.

${ }^{18}$ Muhammad Hambali, Guru Mata Pelajaran Fiqh, Wawancara Pribadi.
} 
students. This perception or connection occurs because of pacing and leading. This was also supported by an interview by Nur Afifah Maulina who said that students feel comfortable when there is a relaxation process that causes connectivity between teachers and their students. This connectivity occurs when students feel comfortable with the learning atmosphere that has taken place, so anything that teachers assign to their students will be immediately carried out. ${ }^{19}$

In addition to pacing, the implementation also uses the leading stage which functions so that students want to obey what their teacher says. This is according to an interview with Muhammad Hambali who said that students will obey what the teacher wants or instructs when the process is leading. When students have entered the leading process, even though the material faced is difficult, students will assume that the material is easy because they have entered in the subconscious. ${ }^{20}$

Based on existing data in the field, the writer can conclude that the leading process is very determining the direction of learning activities. Because if this process has occurred, there has also been connectivity between the teacher and the students so that what the teacher says will be imitated by the students. Likewise the material presented by the teacher, will be easily absorbed by students. For example, when the teacher asks to smile, students immediately smile. Unconsciously, students have entered into the process of relaxation precisely leading. So that with the leading, students will easily absorb the subject matter.

Using positive words is also very necessary in the implementation of this hypnoteaching method. Because with a positive sentence will make students eager to learn. These positive sentences can be in the form of words in the form of praise, for example you are diligent, you are smart, or others. In line with the interview of Muhammad Hambali who said that using positive words can increase students' enthusiasm in

\footnotetext{
${ }^{19}$ Nur Afifah Maulina, Siswa MTs NU Sunan Kalijaga, Wawancara Pribadi.

${ }^{20}$ Muhammad Hambali, Guru Mata Pelajaran Fiqh, Wawancara Pribadi.
} 
learning and be able to make students more intelligent about the material presented. ${ }^{21}$

Providing praise in the form of words or reward or punishment is also the most important thing in the implementation of hypnoteaching methods. Because with the praise will make students become enthusiastic in learning. The form of rewards given by teachers to their students can be in the form of words or behavior. For example, say you're diligent, you're great. Whereas in the form of behavior is usually in the form of applause or shoulder clap. This is according to what was revealed by Muhammad Hambali that giving praise is very positive effect on the learning process of students, because it can indirectly motivate students themselves. The giving of praise is usually in the form of positive words that use words, whereas by touch they usually use applause or applause. ${ }^{22}$

In addition, mastering the material also really needs to be owned by a teacher. Because without mastering the material, the teacher will not be able to carry out learning well. A teacher must have a pedagogical ability in which must master the material to be taught to students. In line with the expression of Muhammad Hambali who said that a teacher in order to convey material well to students must first master the material. ${ }^{23}$

\section{Evaluation Aspect}

In every method of learning, an evaluation is definitely needed. Evaluation is carried out to determine the level of student success, and the ability of students during the learning process. Evaluation in the implementation of hypnoteaching method is not much different from other methods. For example using oral tests, questions and answers and discussions. Usually when the method is often used, student evaluations using questions and answers there are only a few students who are enthusiastic about the questions given by a teacher.

\footnotetext{
${ }^{21}$ Muhammad Hambali, Guru Mata Pelajaran Fiqh, Wawancara Pribadi.

${ }^{22}$ Muhammad Hambali, Guru Mata Pelajaran Fiqh, Wawancara Pribadi.

${ }^{23}$ Muhammad Hambali, Guru Mata Pelajaran Fiqh, Wawancara Pribadi.
} 
What is different from the evaluation this time is the response or enthusiasm of students in the question and answer process. High student responses can be seen from the large number of students who raised their fingers when asked. This shows that students have been relaxed so that they are able to follow the learning process and take an active part in the learning process. ${ }^{24}$

Based on the results of research in the field, it can be concluded that this hypnoteaching method is able to make students active in learning activities. This can be proven when many students raise their fingers when given questions and answers. The number of students who point their fingers when the question and answer process is done, then that is what makes the difference between evaluations using ordinary methods compared to using hypnoteaching method..

Analysis of Weakness Factors in Implementation

The weaknesses of the use of hypnoteaching methods in fiqh learning in MTs NU Sunan Kalijaga, namely the lack of teachers who master the hypnoteaching method. The lack of teachers who master this method of hypnoteaching is an obstacle to the implementation of the hypnoteaching method. Based on interviews Muhammad Hambali said that to be able to apply the method, a teacher must be able to master hypnosis first and also must know about learning to use hypnosis, so that only a few people are able to master it. $^{25}$

\section{Conclusion}

Based on the previous explanation, it can be concluded that hypnoteaching is a learning method that synergizes the activities of the learning process with the science of hypnosis. In practice, the hypnoteaching method emphasizes the cognitive, affective and psychomotor aspects of students through positive suggestions. Secondly, the application of hypnoteaching in fiqh learning at the MTs NU Sunan Kalijaga, Adiwerna Tegal, Central Java is running effectively because there is a synergy

\footnotetext{
${ }^{24}$ Hasil Observasi di MTs NU Sunan Kalijaga

${ }^{25}$ Muhammad Hambali, Guru Mata Pelajaran Fiqh, Wawancara Pribadi
} 
between the principles of hypnoteaching and the existing implementation plan. However, an inhibiting factor was still found, namely the lack of competent teachers in the implementation of hypnoteaching.

\section{DAFTAR PUSTAKA}

Amalia, Ema, Ibrahim, "Efektivitas Pembelajaran Fiqih dengan Mengunakan Metode Demonstrasi di Madrasah Ibtidaiyah Negeri Desa Penggage-Muba," JIP: Jurnal Ilmiah PGMI, Vol. 3, No.1, 2017.

Departemen Pendidikan Nasional, "Kamus Besar Bahasa Indonesia Pusat Bahasa, Edisi Ke empat”. Jakarta: PT. Gramedia Pustaka Utama, 2008. 
Hajar, Ibnu,. Hypnoteaching Memaksimalkan Hasil Proses Belajar Mengajar dengan Hpnoterapi. Jogjakarta : Diva Press, 2011.

http://www.slideshare.net/novrizalbinmuslim/buku-ajarhypnoteaching-2013-revisi.Diakses, 21/03/2016.

Islamy, Athoillah, “ Dialectic Motivation, Behavior And Spritual Peak Experience In The Perspective of Islamic Psychology," alfuad journal, Vo.3, No.2, 2019.

Istiani, Nurul, Athoillah Islamy, "Application Of Hypnoteaching Method In Spiritual Values Learning," Irfani, Vol.14, No.1, 2019.

Istiani, Nurul, Athoillah Islamy, "Objektifikasi Nilai-nilai PsikoSufistik dalam Pendidikan Spiritual," Hikmatuna : Journal for Integrative Islamic Studies, Vol.4, No.2, 2018.

Istiani, Nurul, Esti Zaduqisti, “Konsep Strategi Theistic Spritual dalam Layanan Bimbingan Konseling dan Psikoterapi Islam." Religia, Vol. 20, No.2, 2017.

Jaya, Novian Triwidia. Hypnoteaching Bukan Sekedar Mengajar. Bekasi : D-Brain, 2011

Noer, Muhammad, Hypnoteaching For Success Learning. Yogyakarta: Pedagogia, 2010.

Saihu, "Konsep Manusia dan Implementasinya dalam Perumusan Tujuan Pendidikan Islam Menurut Muratdah Mutahhari," Andragogi : Jurnal Pendidikan Islam, Vol.1, No.1, 2019.

Suwanto, "Perbedaan Kemampuan Pemecahan Masalah Matematika Siswa Yang Diajar Menggunakan Hypnoteaching Dan Pendekatan Ctl Pada Pokok Bahasan Pecahan Di Kelas VII SMP Negeri 27 Medan Tahun Ajaran 2011/2012”. Medan: Fakultas Matematika: 
Jurnal Penelitian Universitas Negeri Medan, Juli, XXII, 2012.

Syukrawati, "Pengembangan Metode Pembelajaran Fiqih Untuk Siswa Madrasasah Ibtidaiyah (MI),"

Syukur, Freddy Fadli, "Menjadi Guru Dahsyat Guru yang Memikat Melalui Pendekatan Tehnologi Pikiran Bawah Sadar Hypnoteaching dan NLP”. Bandung: Remaja Rosdakarya, 2010.

Yustisia, N, Hypnoteaching Seni Ajar Mengeksplorasi Otak Peserta Didik. Jogjakarta: Ar-Ruz Media, 2012. 